\title{
An assessment of soil loss and natural hazards in Nepal
}

\author{
Dinesh R. Shiwakoti \\ Geotechnical Investigation Laboratory, Port and Harbour Research Institute, Ministry of Transport, \\ 3-1-1, Nagase, Yokosuka 239-0841, Japan
}

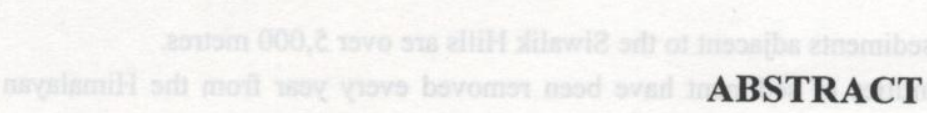

This paper briefly reviews the status of soil erosion in Nepal, and examines the major causes and factors leading to soil erosion and mass movements. There are the following four major mechanisms associated with soil loss: a) surface soil erosion, b) landslide and debris flow, c) earthquake, and d) glacier lake outburst flood.

Effective methods for investigating, analysing, identifying, and implementing the critical factors for protecting accelerated soil loss in a planned manner are essential from the grass roots to national and international levels.
\end{abstract}

\section{INTRODUCTION}

Nepal lies in the Himalayas. The country is broadly divided into the following five major physiographic regions: a) Terai, b) Siwaliks (Churia), c) Middle Mountains, d) High Mountains, and e) High Himalayas (Hagen 1969). These divisions are briefly described in Table 1 (Shiwakoti 1999a).

Nepal is prone to natural as well as human-induced hazards. Each year, several hundreds of lives and properties worth of several millions of dollars are lost, and the soil ecosystem is also disturbed. Earthquake, landslide, debris flow, glacier lake outburst flood (GLOF), avalanche, and cloud burst take toll of life and property in the mountains and sudden flooding in the Terai. When such hazards occur, bridges, roads, and power intakes located in the mountainous regions are destroyed. At the same time landslides and debris flows not only take the fertile field and houses but also add to the sediment load in the river, which in turn washes away the paddy fields located along the bank of rivers in mountain areas. In the Terai area, many paddy fields are either eroded or submerged with floodwater.

An outstanding and recent example of such hazard was caused by heavy rainfall in July 1993. As a result of the floods and landslides, heavy losses of infrastructure, lives, and property were reported. Several districts of the Terai were flooded with water. Heavy landslides occurred in many parts of mountainous regions including Dolakha, Ramechhap, and Panchthar districts, cleaning several villages and causing a great loss of life and property. The Bagmati Barrage, the East-West Highway, the Prithvi Highway, and the Tribhuvan Highway were considerably damaged. The Tribhuvan Highway was severely affected by debris flows, flash floods, washouts, gully erosion, and landslides (Dhital et al. 1993; Dangol et al. 1993; Shiwakoti 1995).

\section{MECHANISMS OF SOIL LOSS AND THE ASSOCIATED HAZARDS}

Various factors are responsible for the formation of soils. These factors are briefly described in Table 2 . Resulting clay mineralogy of representative soils found in Nepal are listed in Table 3.

There are mainly four mechanisms associated with soil loss that cause various hazardous effects in soil ecosystem of Nepal. They are: a) surface soil erosion, b) landslide and debris flow, c) earthquakes, and d) GLOF. The influence of human activities in accelerating and controlling the process of soil loss is also an important factor. A short description of the mechanisms is given below.

\section{Soil erosion}

The landscape of Nepal is an expression of tectonic activities as well as ongoing erosion and sedimentation processes. Erosion processes are complex, consisting of natural erosion and human-induced erosion. Natural erosion rates are extremely high in Nepal because of the constant tectonic uplifting of the major mountain ranges and consequent down cutting by rivers. Natural erosion is characterised by different forms of mass movement, particularly landslides, riverbank cutting, and gully erosion.

\section{Soil erosion by rivers and streams}

The estimated soil loss (Laban 1978) in a typical watershed of the Middle Mountains of Nepal are given in Table 4. Sediment loads for some typical rivers in Nepal are given in Table 5. Table 6 shows an estimate of overall erosion rates in various regions of Nepal (Laban 1978). Tolerance level of soil loss in a watershed indicates the critical rate of soil loss, which can be permitted without causing degradation of land. The value of tolerable soil loss is 
Table 1: Physiographical and geological divisions and their characteristics

\begin{tabular}{|c|c|c|c|}
\hline Zones & $\begin{array}{l}\% \text { of total } \\
\text { land }\end{array}$ & $\begin{array}{c}\text { Elevation } \\
\text { from } \mathrm{msl}(\mathrm{m})\end{array}$ & 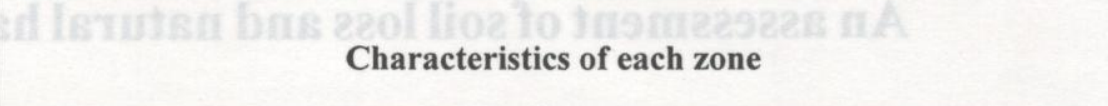 \\
\hline Terai & 14.4 & $60-330$ & $\begin{array}{l}\text { - It consists of Recent and post-Pleistocene alluvial deposits, which form a } \\
\text { piedmont plain adjacent to the front of the Himalayan Mountains. } \\
\text { - Generally, flatlands with minor relief caused by ongoing river action and tectonic } \\
\text { activity. } \\
\text { - Alluvial sediments adjacent to the Siwalik Hills are over } 5,000 \text { metres. } \\
\text { - Vast quantities of sediment have been removed every year from the Himalayan } \\
\text { ranges, and a significant percentage is being deposited within the Terai. }\end{array}$ \\
\hline Siwaliks & 12.7 & 330 & $\begin{array}{l}\text { - It consists of interbedded sandstone, siltstone, shale, and conglomerate. } \\
\text { - It is bordered on the south by the Terai alluvium and on the north by the Main } \\
\text { Boundary Thrust that separates the Lesser Himalaya. } \\
\text { - Soils in the Siwalik hill are unable to retain the high intensity precipitation and the } \\
\text { flashiness of the river system is one of the most notable features. }\end{array}$ \\
\hline $\begin{array}{c}\text { Middle } \\
\text { Mountain }\end{array}$ & 29.5 & 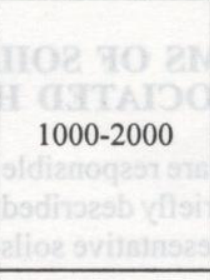 & $\begin{array}{l}\text { - It consists of phyllites, quartzites, micaschists, granites, and limestones. } \\
\text { - The southern margin consists of a high mountain range (the Mahabharat Lekh). } \\
\text { - Rocks are highly fractured. } \\
\text { - Soil formed on high terraces or valley terraces are remnants of past valley- } \\
\text { damming events possibly GLOF deposits. } \\
\text { - Rainfall is less intense. }\end{array}$ \\
\hline $\begin{array}{c}\text { High } \\
\text { Mountain }\end{array}$ & 1 & $2000-3000$ & $\begin{array}{l}\text { - This region is characterised by metamorphic rocks. Gneisses and garnetiferous } \\
\text { micaschists are much more common. Almost all valleys show glaciated landforms. } \\
\text { - Active river downcutting has resulted in tremendous canyons. } \\
\text { - Soil weathering is quite limited. Rainfall intensities are considerably lower. } \\
\text { - The soils in the upper reaches of the High Mountain valleys are the result of } \\
\text { physical rather than chemical weathering. Rocks are very coarse and acidic. }\end{array}$ \\
\hline $\begin{array}{c}\text { High } \\
\text { Himalaya }\end{array}$ & 23.7 & $3000-8848$ & $\begin{array}{l}\text { - The zone resembles alpine and "arctic" climatic regimes. There are active glacier } \\
\text { systems and there is sufficient precipitation. } \\
\text { - Glacier basins, U-shaped valleys, moraines, hanging valleys, and avalanche slopes } \\
\text { are characteristic landforms. Over } 86 \% \text { of the region is covered by bare rock. } \\
\text { - Gneisses, schists, limestones, and shales are predominant. Physical weathering is } \\
\text { very high. Unconsolidated sediments consist of boulders, gravels, sand, and silt. }\end{array}$ \\
\hline
\end{tabular}

different for each watershed. In the USA, the tolerable soil loss is reported as 4.5-11.2 tons/ha/year (Wischmeier and Smith 1978). Considering that Nepal is a mountainous country, probably, the average tolerable soil loss should be in the range of $5-20$ tons $/ \mathrm{ha} / \mathrm{yr}$.

According to the land degradation study of a watershed in eastern Nepal (Trijunga Watershed) done by Sah et al. (1997), there was an increase in topsoil loss from 12.5 to 18 tons/ha/yr between 1978 and 1991, which is an increment of $44 \%$. During the same period, the loss of forest was $0.57 \%$ per year. Between 1991 and 1996, they reported the loss in overall crop productivity for the area by more than $15 \%$. Land degradation speed of the watershed is inversely related to the socio-economic status of the inhabitants, and directly related to the sensitivity of the location (which is the ratio of soil loss increment to forest loss).
Erosion processes profoundly affect the overall economy and the health of the nation. The loss of topsoil from cultivated and grazing lands causes decline in soil fertility. Sedimentation, in conjunction with peak discharges results in abrupt river channel changes causing tremendous hardships for farmers on the alluvial lands of Nepal. Similarly, high sediment loads of rivers quickly reduce the useful storage capacity of man-made reservoirs, silt up irrigation canals, and damage turbines and water control structures.

\section{Role of rainfall in soil erosion}

Loss of topsoil by surface erosion is the outcome of heavy rains pounding unprotected and barren outcrops. Many of human activities cause the soil to become less protected than it would have been in its natural state. The 
Table 2: Major factors responsible for the formation of soils in Nepal Himalayas

\begin{tabular}{|c|c|}
\hline Factors & Description \\
\hline Climate & $\begin{array}{l}\text { It has a profound effect on landscape formation. The extreme range of temperature, precipitation, and } \\
\text { humidity in various seasons in Nepal cause an equally wide range of weathering regimes for soil formation. } \\
\text { Over } 80 \% \text { of concentrated rain falls during the monsoon. } \\
\text { In the Terai region, climate is hot and humid. Chemical weathering is very significant. Physical weathering is } \\
\text { predominant in areas with low rainfall and humidity. In inner Dolpa, physical weathering is dominant on steep } \\
\text { slopes. Intense chemical weathering occurs in the Middle Mountain region with mountain slopes ranging from } \\
20 \text { to } 30 \text { degrees. } \\
\text { The Siwaliks with the same slope angle, where rainfall is more intense, might have a much less weathered soil } \\
\text { profile than an equivalent slope in the High Mountains due to continuous washout of the surface soil in the } \\
\text { Siwaliks by rains and floods. }\end{array}$ \\
\hline & $\begin{array}{l}\text { Change in relief is the dominant factor in landscape and therefore of soil stability. The steeper the slope is the } \\
\text { shallower is the unconsolidated material on the slope, and it is more likely that erosion processes remove any } \\
\text { material on the slope. }\end{array}$ \\
\hline Biotic factor & $\begin{array}{l}\text { Presence and nature of vegetation in a given area directly influences the rate of weathering and soil formation. } \\
\text { The land covered by vegetation experience a lesser degree of soil loss. }\end{array}$ \\
\hline Human factor & $\begin{array}{l}\text { Human activity may increase or decrease the rate of soil erosion. There has been an increased rate of soil } \\
\text { erosion by disturbing vegetation from various activities such as ploughing, burning, livestock grazing, re- } \\
\text { directing surface water from natural drainages (e.g., for irrigation, road construction etc.). } \\
\text { Bench terrace construction enhances greatly the soil characteristics and ultimately its pedogenetic } \\
\text { development. The reduction of effective slope gradient, the effect of irrigation water, the cultivation on the } \\
\text { topsoil, and the new nutrient cycling on terraces, cause the soil to develop in a different manner than nearby } \\
\text { untouched sites. }\end{array}$ \\
\hline $\mathrm{C}$ & The age of a soil greatly affects its properties. Soil profiles evolve gradually during the time span. The soils in \\
\hline
\end{tabular}

Table 3: Clay mineralogy of major soils in various parts of the Nepal Himalayas (LRMP 1986)

\begin{tabular}{l|l|l|l}
\hline \multicolumn{1}{c|}{ Soil type and its location } & \multicolumn{1}{c}{ Degree of abundance } \\
\cline { 2 - 4 } & \multicolumn{1}{c}{ Major 25\% } & \multicolumn{1}{c}{ Intermediate $\mathbf{0 - 2 5 \%}$} & kaolinite \\
\hline Udic Rhodustalf on ancient terrace & smectite & vermiculite-chlorite & kaolinite \\
Typic Haplumbrept on mica schist & mica & vermiculite-chlorite & kaolinite, quartz \\
Lithic Dystrochrept on Siwalik sandstone & vermiculite-chlorite & quartz, smectite, illite, mica & quartz \\
Anthropic Eutrochrept on till & vermiculite-chlorite & illite, mica, smectite, kaolinite & vermiculite-chlorite, illite, smectite \\
Anthropic Eutrochrept on gneissic colluvium & mica, smectite & quartz \\
Eutroboralf on mica schist & vermiculite-chlorite & illite, smectite, kaolinite, mica & quartz \\
Udic Rhodustalf on phyllite & illite & vermiculite-chlorite, kaolinite, smectite & quartz \\
\hline
\end{tabular}

Table 4: Estimated soil loss for different land uses (Laban 1978)

\begin{tabular}{l|c}
\hline \multicolumn{1}{c|}{ Type of land } & $\begin{array}{c}\text { Estimated Soil } \\
\text { Loss (Tons/ha/yr) }\end{array}$ \\
\hline Well managed forest land & $0-10$ \\
Well managed rice terraces (bunded) & $0-10$ \\
Well managed maize terraces & $5-15$ \\
Poorly managed sloping terraces & $20-100$ \\
Degraded range land & $40-200$ \\
\hline
\end{tabular}

magnitude of surface soil erosion is directly related to the intensity of precipitation. Rainfall intensity decreases with increasing elevation. Consequently, the Terai has higher rainfall intensity while the Higher Himalayas have lower. Slopes in the Terai or Siwaliks experience more erosive storms than those in the High Mountains.

Mean annual rainfall ranges from less than $250 \mathrm{~mm}$ in the northern part of central Nepal, to $6000 \mathrm{~mm}$ in the southern part. Annual average rainfall for most of the country is about $2000 \mathrm{~mm}$. About $80 \%$ of the rainfall occurs during the monsoon period (end of June to middle of September). During this period, rainfall with intensity of $70-100 \mathrm{~mm} / \mathrm{hr}$ is not so 
Table 5: Sediment loads in some Nepalese Rivers (modified from LRMP 1986)

\begin{tabular}{llccc}
\hline River & $\begin{array}{c}\text { Catchment area } \\
\left(\mathbf{k m}^{2}\right)\end{array}$ & $\begin{array}{c}\text { Total annual sediment } \\
\text { load }\left(\mathbf{m}^{3}\right)\end{array}$ & $\begin{array}{c}\text { Sediment load intensity } \\
(\text { ton/ha/yr) }\end{array}$ & $\begin{array}{c}\text { Erosion rate } \\
(\text { ton/ha/yr) }\end{array}$ \\
\hline Tomur & 5900 & $29.6 \times 10^{6}$ & 50 & 150 \\
Arun & 36533 & $34.6 \times 10^{6}$ & 10 & 30 \\
Sunkoshi & 19230 & $54.2 \times 10^{6}$ & 28 & 84 \\
Bagmati & 585 & $2.7 \times 10^{6}$ & 46 & 138 \\
Trisuli & 4110 & $7.6 \times 10^{6}$ & 19 & 57 \\
Karnali & 42890 & $220 \times 10^{6}$ & 51 & 153 \\
\hline
\end{tabular}

uncommon. Fetzer and Jung (1978) estimated the erosivity of about $70 \%$ for the northwestern mountain ridge of the Kathmandu Valley. Since rainfall intensity data are scarce in Nepal, direct assessment of rainfall intensity throughout the country is very difficult.

\section{Soil erodibility}

Soil characteristics including texture, percentage of organic matter, structure, and rate of infiltration can significantly affect erodibility of soil. In general, the less the proportion of fine sand, silt, and clay, the higher is the infiltration rate, and the less erodible the soil is. Red soils in Nepal are prone to sheet and gully erosions because of their low infiltration rates, tendency toward surface crusting, and lack of aggregate stability. Overgrazing and burning on red soils induce severe soil degradation. Structureless and very fine lacustrine sands are also extremely erodible. Even low intensity storms may result in an intense topsoil erosion.

\section{Slope angle and length}

As slopes become steeper and longer, the potential for surface soil erosion increases. The higher the velocity and the greater the concentration of water, the greater will be the sheet and rill erosion. On gentle slopes, the effects of topsoil erosion are generally more significant than mass wasting, whereas at slopes greater than 30 degrees, landslides, and debris flows begin to outweigh the effects of surface erosion.

\section{Vegetation}

The protection of bare soil by crops or natural vegetation helps to lessen the soil erosion due to rainfall. The greater the density of vegetation is, the less is the erosion of the soil surface. Overgrazed lands result in the most severe surface erosion, while dense and multi-storeyed forests have the lowest levels of topsoil erosion.

\section{Role of terrace development}

By reworking hill slopes into bench terraces, and maintaining lined or vegetated waterways with adequate drop structures, rate of soil loss can be decelerated on a cultivated slope. In Nepal, farmers have developed a stable agricultural
Table 6: Overall erosion rates in different land areas of Nepal (Laban 1978)

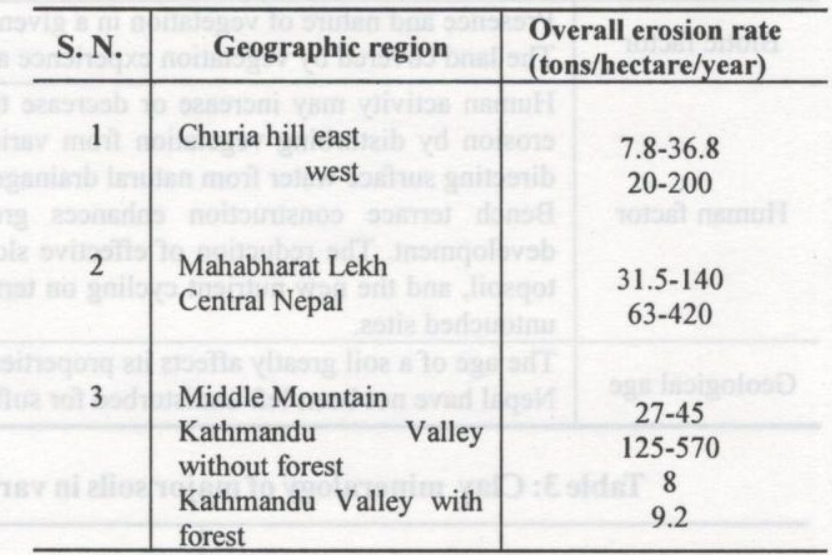

system for their cultivated corps by constructing and maintaining bench terraces and integrated farming system.

Typical topsoil erosion and associated nutrient losses by rainfall are shown in Table 7 . As can be seen, wellmanaged and levelled terraces experience only minor soil loss. Land used for shifting cultivation and sloping terraces suffer huge loss of soil and associated fertility.

\section{Effect of wind in soil erosion}

Although erosion induced by rainfall is the major topsoildegrading factor, wind erosion is also playing a significant role on certain landscapes associated with cultivation. Wind erosion is significant in the High Himalayan valleys, particularly in Dolpa, Mustang, and Manang, owing to their semi-arid and arid climate. The Kali Gandaki at Jomsom experiences tremendous winds daily. These winds are strong enough to move coarse sand along the valley floor. The area is so dry that vegetation is restricted to scattered thorny scrubs growing on bare soil.

Dust storms occur on and adjacent to all major dry riverbeds, which comprise $1.6 \%$ of Nepal. Bare and riverbed sediments are easily windblown and can be carried for long distances. This process causes silt deposition on forested 
Table 7: An estimate of soil and nutrient losses by rainfall erosion based on land use mode (Carson 1985)

\begin{tabular}{|l|c|c|c|c|}
\hline \multicolumn{1}{|c|}{ Title } & $\begin{array}{c}\text { Irrigated rice } \\
\text { land }\end{array}$ & $\begin{array}{c}\text { Level } \\
\text { terraces }\end{array}$ & $\begin{array}{c}\text { Sloping } \\
\text { terraces }\end{array}$ & Shifting cultivation \\
\hline Soil loss depth (mm) & 0 & 0.4 & 1.6 & 8.0 \\
\hline Soil loss (ton/ha/yr) & 0 & 5.000 & 20.000 & 100.000 \\
\hline Organic matter loss (ton/ha/yr) & 0 & 0.150 & 0.600 & 3.000 \\
\hline Nitrogen loss (ton/ha/yr) & 0 & 0.008 & 0.030 & 0.150 \\
\hline Phosphorus loss (ton/ha/yr) & 0 & 0.005 & 0.020 & 0.100 \\
\hline Potassium loss (ton/ha/yr) & 0 & 0.001 & 0.040 & 0.200 \\
\hline
\end{tabular}

and cultivated lands, particularly in the Terai and Siwaliks, because the majority of dry riverbeds are found there.

Throughout the Middle Mountains, wind erosion is of minor importance, because the soils have medium textures and good structures, and hence they are able to resist wind erosion. In addition, cultivated soils are protected even in the peak windy season.

To minimise topsoil loss by wind, any activity that exposes the soil needs to be combined with good erosion management including afforestation, windbreaks, surface protection, and irrigation.

\section{LANDSLIDES AND DEBRIS FLOWS}

Many Himalayan landscapes have a period of a relative stability of slopes when mass wasting is not a dominant processes followed by an instability during which a large number of landslides occur almost simultaneously on an otherwise undisturbed slope. Generally speaking, landslides, debris flows, and soil creep occur in different parts of Nepal in varying degrees during the rainy season.

Major factors contributing to mass movements in Nepal can be attributed to its fragile geology, steep slopes, concentrated precipitation, high river gradient, and an alarming rate of deforestation. Highly fractured rocks, and undercutting of banks by deeply incised rivers and streams contribute significantly to excessive mass wasting in mountainous terrain. Highly concentrated precipitation during the three months of monsoon season (more than $80 \%$ of annual rainfall is concentrated within July-September) is another detrimental factor in this list.

In the Mahabharat Range, where rocks are hard and channels are deep, rock and soil slides are common. Sometimes, during the heavy rain, landslide dams occur and when they breach, cause heavy damages downstream (e.g., the Tinau River in the Tansen area). In the Churia hills, mostly rock and soil slides are founds.

In the Midlands of Nepal, soil slides are more common due to cultivation and deforestation and also due to toe cutting by the river wherever it takes a turn. In the Middle
Mountains, river channels are wide and scarcely dammed by a slide. In the eastern part of Middle Mountains, phyllites, shales, and schists showed no significant differences in the degree or type of mass wasting, while the deeply weathered gneisses seemed considerably less hazardous to sliding but much more prone to piping and gully formation. In areas where the weathering is deep and soil outcrop is exposed, the soil creep may occur due to undercutting by river or by human-induced activities. Major factors contributing to the natural instability and resulting mass movements in Middle Mountains are: structure and inclination of slope; number and density of natural fracture planes; type of rock or mineral and state of weathering; and the presence of water (Wagner 1983).

In the northern part of Nepal, where rocks are weak, slopes are steep, and rivers make deep gorges, rockslides are very common. Labubensi in the upper reaches of the Budhi Gandaki River is an example. In this belt, the river courses are narrow and deep, hence are easily blocked by landslides.

Human activities have also greatly contributed in accelerating landslide and debris flow in Nepal. These activities include: infrastructure development (such as construction of roads, the failure of which accounts for about $5 \%$ of total landslide), irrigation canals or dams without proper engineering insight and input, unscientific ways of quarrying of construction materials, haphazard way of extracting minerals, dumping of road wastes and excavated wastes on sloping land, intensive deforestation, removal of vegetal cover for agricultural purposes on steep slopes, overgrazing, irrigation on steep slopes etc.

\section{EARTHQUAKES AND TECTONIC ACTIVITIES}

Nepal has experienced earthquakes of large magnitudes from time to time over the past several centuries. The earliest recorded earthquake mentioned in ancient writings occurred in 1255 and is estimated to have a magnitude of approximately 7.7 on Richter's Scale. These earthquakes are causing heavy loss of life, injuries, property loss, and damage in Nepal, in addition to the soil loss. 
The build up of tectonic stresses accompanying the interplate collision results in the accumulation of strain and the abrupt failure of rocks in the earth's crust along major fault systems. In Nepal and the surrounding regions, these major fault systems lie parallel to the axis of the Himalayan range and include from north to south, the Indus Suture Zone (ISZ), the Main Central Thrust (MCT), and the Main Frontal Thrust (MFT).

According to an estimate (BCDP 1988), there are at least ninety-two active faults or fault segments within Nepal. The active faults include thrusts and reverse faults, normal faults, and, strike slip and oblique-slip faults.

The three seismic areas within Nepal and the surrounding regions that may be considered to be seismic sources, and that are intended to simulate the effects of subduction zone earthquakes, have been identified and characterised using the tectonic and seismicity data (BCDP 1988). The three interpreted seismic areas are intended to represent earthquakes of the Himalayan subduction zone detachment source that exists at depth beneath Nepal and the surrounding region. Earthquakes within the seismic areas are assumed to occur anywhere within the area boundary at the specified depth. The maximum magnitudes of earthquake for the northern, middle, and southern seismic areas are 8, 8.5, and 7.5 respectively, whose specified focal depths are 60 , 40 , and $10 \mathrm{~km}$, respectively.

\section{GLACIER LAKE OUTBURST FLOOD (GLOF)}

Most of glacier lakes are found towards the east of Pokhara. In case of rivers like Arun, Bhote Kosi, Sunkosi, Bhotekosi-Trisuli, and Karnali, some dangerous lakes lie in the Tibetan side. Study by Water and Energy Commission Secretariat has found nearly 13 such lakes in the Dudh Kosi (river) basin alone. The size of lakes varies from 0.40 to 9.23 hectares in surface area and they lie at elevations from 4300 to $4600 \mathrm{~m}$ above sea level. Recent survey has identified five glacier lakes in the Likhu Khola, which range in size from 0.40 to 6.02 hectares and lie at an altitude of $4200-4600 \mathrm{~m}$ (Yamada 1993).

Influence of GLOF reaches up to the Middle Mountains. It also contributes to the sediment load in the river, and may even cause a change in river course. The changes in the Kosi River course in the past is inferred to be due to the sudden release of sediment from GLOF that occurred in all its three major tributaries (i.e. the Tamur, Arun, and Sun Kosi).

The GLOF phenomenon was detected only after the destruction of the Namche Bazaar Small Hydroelectric Project in 1985 from the breaching of the Dig Cho Glacier Lake (Viuchard and Zimmermann 1986). Subsequent investigation by Water and Energy Commission Secretariat highlighted the following past GLOF events. In 1981, in the head region of Bhote-Sunkoshi a GLOF occurred, which wiped out a fairly large section of the Kodari Highway and the Miteri Pul (bridge). Similarly, GLOF occurred in the Barun Khola in 1981; in the Tamur in 1980; at Nare Drangka below Amadamlam in 1977; in the Arun River in 1964; in the Trishuli River and the Bhote Kosi basin in 1964 and 1968 respectively; and in the Arun basin in 1969 (Yamada 1993).

\section{ROLE OF HUMAN ACTIVITY IN SOIL LOSS}

Activities related to road construction, for example, are among the major factors contributing to the soil loss in various forms. About 400 to $700 \mathrm{~m}^{3}$ of landslide per $\mathrm{km}$ are reported to be occurring every year in the hill roads. From 10 to $25 \%$ of hill roads following river valley are completely washed out in every four to five years.

Construction of roads by high and steep back cutting, uncontrolled disposal of waste material, inadequate sizing of longitudinal and cross drains, and destabilisation of runoff pattern in the downhill slope by concentrated discharge without proper downstream protection are common. In traditional practice of designing road cross-sections of the hills, instabilities arising from toe cutting at the downstream of the slope, and erosion, gulling, and landslides in the upper and lower slopes are not accounted for. Excessive discharges from torrential rains, cloudbursts, high run-off, temporary landslide damming, rise in groundwater table from heavy rainfall and temporary rises in river level are not adequately addressed (Shiwakoti 1999b).

Similarly, over the last century, an increasing proportion of soil loss is attributable to accelerated erosion induced by increased population pressure on the limited land resource. Forest clearing, overgrazing, poorly maintained sloping lands, and forest fires have greatly altered the natural vegetation of Nepal, making the topsoil vulnerable to degradation and loss.

Effective methods for investigating, analysing, identifying, and implementing the critical factors for protecting accelerated soil loss in a planned manner are essential from the grassroots to national and international levels.

\section{MEASURES FOR MITIGATING SOIL LOSS AND RELATED HAZARDS}

Nepal lacks not only the financial and technical strength necessary to adequately tackle the problem of land degradation and its related issues, but also there is a ambiguity/conflict among various governmental institutions, which are responsible for controlling and mitigating the problem.

Based upon the dimension of the problem and extent of its implication, various strategies should be formulated and applied in various hierarchy levels to mitigate soil loss, and 
float it into the effective, sustainable, and enduring framework. Depending on the magnitude, nature, and the scope, such problems should be tackled at people's level, local government level, national government level, intergovernment level, or international level.

Proper planning and execution/supervision of infrastructural development projects in institution level need not be overemphasised in reducing soil loss and in stabilising outcrops. Terrain-specific engineering codes and procedures should be developed and implemented for each type of infrastructure. Irrigation canals, for example, should be properly lined and should be constructed and maintained at adequate grades. River training works are crucial in easing loss of land and soil from local to national level. Similarly, roads should be constructed following scientific and environment-friendly methods to reduce road-induced landslides and soil erosions. Enhanced forestation of barred lands should be executed from local organisation level, and regional level to national levels. Various research facilities should be opened in regional and national level to have understanding of the nature of specific problems and to find optimum solutions.

This type of works, however, needs understanding and co-operation at various levels, which may not be easy in many cases. Furthermore, for an underdeveloped country like Nepal, associated financial burden could be a major constraint to execute such works with high priority.

Implementation of integrated and systematic farming system by the grassroots can considerably reduce the rate of accelerated loss of soils from Nepalese Mountain. Maintenance of terraced farming grounds out of sloping lands, and employment of integrated farming system consisting of planting trees and other vegetation in farming land, can contribute significantly towards controlling the excessive soil loss and its consequences. In addition, awareness for forest preservation among people, improvement in mode and efficiency of fuel energy, increase in private and community forests, provision of controlledgrazing, and control of fire in jungle can be very effective ways of reducing soil loss.

\section{CONCLUSIONS}

A very high rate of soil loss in mountainous regions of Nepal in various forms (such as surface soil erosion, landslides, and debris flow etc.) is causing a great loss in terms of economy and life of people, as well as severely threatening the stability of overall ecological system of the region.

Effective methods for investigating, analysing, identifying, and implementing the critical factors for protecting accelerated soil loss in a planned manner are essential from the grassroots to national and international levels. To take this problem, it is necessary to have pre- understanding and preparedness in terms of chosen levels of design types, infrastructure conditions, and expected failures. Continuous and vigorous communication/coordination among designers, maintenance engineers, decision-makers, and the people give way to play an important role in soil erosion control.

\section{REFERENCES}

BCDP, 1988, Seismic Hazard Mapping and Risk Assessment study made by National Building Code Development Project, BCDP (UNDP Project NEP/88/054).

Dhital, M. R., Khanal, N., and Thapa, K. B., 1993, The role of extreme weather events, mass movements, and land use changes in increasing natural hazards. A report of the preliminary field assessment and workshop on : causes of the recent damage induced in south-central Nepal, published by International Centre for Integrated Mountain Development, Nepal, 123 p.

Dangol, V., Shakya, U., Wagner, A., and Bhandari, A. N., 1993, A landslide inventory study (after the disaster of July, 1993) along the Tribhuvan Highway, Central Nepal. Bull. of Dept. of Geol., Tribhuvan Univ., Kathmandu, Nepal, v. 3(1), Sp. Issue, pp. 59-69.

Carson, B., 1985, Erosion and sedimentation processes in the Nepalese Himalaya. ICIMOD, Kathmandu, Nepal, Occasional Paper No. 1, 39 p.

Laban, P., 1978, Field measurement on erosion and sedimentation in Nepal. Department of Soil Conservation and Watershed Management, Kathmandu, Nepal, No. 5 (FAO/UNDP, IWM/ WP/05).

Land Resource Mapping Project (LRMP), 1986, Land system report: The soil landscapes of Nepal. Submitted by Kenting Earth Sciences Limited to HMG/N, 140 p.

Fetzer, K. D., and Jung, L., 1978, Factors affecting soil erosion by water within a research area of northwestern mountain ridge of Kathmandu valley. Journal of the Nepal Research Centre, v. 2(3).

Hagen, T., 1969, Report on the Geological Survey of Nepal. Preliminary Reconnaissance. Denkshr. Schweiz. Naturforsh. Ges., 8611, Zurich, v. 1, pp. 1-185.

Sah, B. P., Honda, K., and Murai, S., 1997, Land degradation and socio-economic status modelling by using remote sensing and GIS for watershed management. Asian-Pacific Remote Sensing and GIS Journal, Bangkok, Thailand, v. 9(2), pp. 51-61.

Shiwakoti, D. R., 1995, Geotechnical Problems in Nepal, A special study report submitted to Yokohama National University, Yokohama, Japan, 43 p.

Shiwakoti, D. R., 1999a, Soil Erosion and its Control in Mountainous Regions of Nepal. First Asia-Pacific Conference on Ground and Water Bioengineering for Erosion Control and Slope Stabilization, Manila, Philippines, pp. 1-10.

Shiwakoti, D. R., 1999b, Present status of transportation network in Nepal mountains and it sustainability. International Student Seminar on Transport Research'99 (ISSOT'99), September 13-14, 1999 Taipei, Taiwan, pp. 10-19.

Vuichard, D. and Zimmermann, M., 1986, The langmoche flash flood Khumbu Himal, Nepal Mountain Research and Development, v. 6(1). 


\section{Dinesh R. Shiwakoti}

Wagner, A., 1983, The principal geological factors leading to landslides in the foothills of Nepal, A statistical study of 100 landslides. Helvetas, Swiss Technical Cooperation, ITECO (Unpublished Report).
Wischmeier, W. H. and Smith, D. D., 1978, Predicting Rainfall Erosion Losses. A Guide to Conservation Planning, U.S. Department of Agriculture, Handbook, No. 537, 58 p.

Yamada, T., 1993, Glacier lakes and their outburst floods in the Nepal Himalaya. JICA-NEPAL, 37 p. 